\title{
THE EFFECT OF VOLUNTARY IFRS ADOPTION BY UNLISTED FIRMS ON EARNINGS QUALITY AND THE COST OF DEBT: EMPIRICAL EVIDENCE FROM KOREA
}

\author{
Young Hwan LEE ${ }^{1}$, Sun A KANG ${ }^{2}$, Sang Min $\mathrm{CHO}^{3}$ \\ ${ }^{1}$ Department of Business Administration,Kumoh National Institute of Technology, \\ 61 Daehak-ro, Gumi, Gyeongbuk 730-701 Korea \\ ${ }^{2}$ Department of Business Administration, Chungnam National University, \\ 99 Daehak-ro, Yuseong-gu, Daejeon 305-764 Korea \\ ${ }^{3}$ Department of Business Administration,Hannam University, 70 Hannamro, \\ Daedeok-gu, Daejeon 306-818 Korea \\ E-mails: ${ }^{1}$ leeyh@kumoh.ac.kr; ${ }^{2}$ sunakang@cnu.ac.kr (correspondingauthor); \\ 33hosmcpa@hanmail.net
}

Received 28 October 2013; accepted 08 August 2014

\begin{abstract}
The present study empirically examines how voluntary International Financial Reporting Standards (IFRS) adoption influences the earnings quality and the cost of debt of unlisted firms in Korea. Since 2011, when the adoption of IFRS by listed firms became mandatory, more unlisted firms have adopted IFRS voluntarily, improving the transparency and reliability of their accounting information. Using the sample of unlisted firms with 3year study period of pre- and post-IFRS adoption, we examine whether IFRS voluntary adopters show both lower discretionary accruals and the cost of debt than those of non adopters, and whether both discretionary accruals and the cost of debt of voluntary adopters decrease after IFRS adoption. We employ the Heckman's two stage approach in order to avoid sample selection bias and cross sectional pooled OLS regression with or without clustering test. We complimentary report the results from firm-fixed effect panel model to generalise the results. The results show that firms which adopt IFRS have a higher earnings quality and a lower cost of debt that those which do not. These findings suggest that when unlisted firms issue bonds and borrow money, IFRS adoption contributes to decreasing the cost of debt.
\end{abstract}

Keywords: international financial reporting standards, earnings management, voluntary adoption, unlisted firm, cost of debt, accounting information, earnings quality, discretionary accruals.

JEL Classification: M40, M41, M48, G30.

\section{Introduction}

Since 2011, when Korean listed firms first mandatorily adopted International Financial Reporting Standards (IFRS), the influence of this change in accounting standards has drawn considerable attention from business and academia alike. In particular, 
researchers and practitioners have assessed how these newly adopted global accounting standards influence firm performance and how the capital market has responded to these changes (Auer 1996; Ball et al. 2003). Because IFRS focuses on the principles of fair value and economic substance, however, some temporary confusion may be expected, such as increased levels of judgment by accounting professionals and therefore a decrease in levels of comparability by firm and period. Furthermore, the adoption of IFRS in Korea is only mandatory for listed firms; unlisted firms are exempt from mandatory IFRS adoption and can still prepare their financial statements under Korea's accounting standards (KGAAP hereafter). However, according to the recent report by the Financial Supervisory Service (2011) ${ }^{1}$, approximately $10 \%$ of unlisted firms in Korea have implemented IFRS voluntarily since 2009, when the Korean government allowed early adoption. The present study therefore empirically examines the effect on two financial indicators, namely earnings quality and the cost of debt, when unlisted firms voluntarily adopt IFRS compared with KGAAP. Although previous studies have examined the adoption of IFRS in Korea, they have tended to focus on early rather than voluntary adoption, and even then the limited sample sizes have made it hard for researchers to generalise the results. However, no studies have thus far analysed the factors that determine whether unlisted firms adopt IFRS voluntarily, which could also be influenced by the external environment. If IFRS adoption by unlisted firms improves the transparency and reliability of financial information, we could expect a positive effect on the Korean economy overall. We find that unlisted firms that voluntarily adopt IFRS show a higher earnings quality and a lower cost of debt than those adopting KGAAP. Firms report no change in earnings quality but a lower cost of debt after conversion to IFRS. These findings suggest that the main reasons for voluntarily adopting IFRS are a desire for consistency with the parent-listed company and an increase in the availability of long-term debt; thus such firms benefit from a lowering of their borrowing costs. The remainder of the present paper is organised as follows. Section 2 is a review of previous studies of IFRS adoption. Section 3 contains the research design and sample selection procedure, and formulates some hypotheses. In Section 4 we discuss the empirical results, and in the last Section we present some conclusions and limitations.

\section{Literature review}

Few studies have used primary research methods, including surveys, to investigate the factors that drive firms to adopt IFRS early. In this vein, Ashbaugh (2001) investigated non-US firms listed on the London stock market, while Kim and Kang (2010) researched listed firms that adopted IFRS early in Korea. Ashbaugh's study (2001) of non-US firms listed on the London stock market examined the motivating factors for their choice of IFRS or USGAAP as opposed to the accounting standards of their respective countries. The author reported that the sample firms chose IFRS when their stocks were traded on overseas stock markets, when they needed to provide

\footnotetext{
${ }^{1}$ Press release from Financial Supervisory Service (http://www.etnews.com/news/economy/economy/2497255_1493.html).
} 
standardised information, or when they planned paid-in capital increases. According to Kim and Kang (2010), listed firms were early adopters of IFRS in order to improve the reliability of their financial statements, to improve their financial structure, and to file consolidated financial statements. In studying the effectiveness of IFRS, most authors have examines earnings quality or asymmetric information in order to understand whether the adoption of IFRS is suitable and what effect it has. For example, Barth, Landsman and Lang (2008) found that the earnings quality of firms that adopted IFRS is higher than that of non-adopters. A number of authors have found an improvement in earnings quality, including Gordon et al. (2009), Gebhardt and Novotny-Farkas (2011), and Barth et al. (2012). By contrast, others found no improvement in their earnings quality (Christensen et al. 2008; Capkun et al. 2011). While Yeo, Koh and Kim (2007) and Jeanjean and Stolowy (2008) suggested that each country that has adopted IFRS has shown different effects on earnings management, including some cases of increased earnings. In terms of information asymmetry, Leuz and Verrecchia (2000) and Ashbaugh and Pincus (2001) found that IFRS adoption decreases investors' information asymmetry. Hail et al. (2010) reported increasing liquidity and a lowering of the cost of capital via a reduction in information asymmetry according to the IFRS. Further, Daske, Hail, Leuz and Verdi (2008) showed that this information asymmetry decreases the cost of capital and increases firm value. Recently, Brochet et al. (2013) focused on the comparability of financial statements following the mandatory adoption of IFRS and found an improvement in terms of comparability and capital market benefits. They suggested that the cause of this improved comparability stems from the reduction of the ability of insiders to access private information. Some authors reported improvements in the forecasting environment affecting financial analysts, in terms of its accuracy or coverage, for example (Tan et al. 2011; Horton et al. 2013). Some studies showed positive capital market consequences after the mandatory adoption of IFRS, including positive abnormal returns during the transitory period of IFRS (Armstrong et al. 2010) and increases in the informativeness of stock prices (Beuselinck et al. 2009). At the same time, however, Kim (2011) found no significant differences in information asymmetry (and earnings quality) between early and late adopters in Korea. Christensen, Hail, and Leuz (2013) argued that capital market effects could be mixed with changes in enforcement given a lack of evidence of market liquidity in IFRS countries. Based on this inconclusive evidence, Kang, Han and Hwang (2009) claimed that it is necessary first to examine the previous accounting environment, the social and cultural traditions of a country, industry or individual firm, as well as any previous accounting standards, in order to analyse earnings differences between pre- and post-IFRS adoption. Because all Korean studies of IFRS implementation have investigated early adopters, they have suffered from the drawback of limited samples of firms, which could have led to inconsistent and ungeneralisable results. By contrast, the target firms in our present research are unlisted firms in Korea, which outnumber listed ones by a factor of ten to one. Of these, an estimated 842 unlisted firms have adopted IFRS voluntarily. Therefore, in the present paper we use this sample to analyse the factors that drive voluntary IFRS adoption and empirically examine the effect of IFRS adoption on earnings quality and the cost of debt. 


\section{Hypothesis development and research design}

\subsection{Factors that drive IFRS adoption by unlisted firms}

Unlike listed firms in Korea, unlisted enterprises are not obliged to adopt IFRS, but some do so voluntarily. First we present Model 1, which analyses the factors that drive voluntary IFRS adoption by unlisted firms based on the motivating factors for listed firms in the literature (Ashbaugh 2001; Kim, Kang 2010). The characteristics of listed firms that adopt IFRS voluntarily can be summarised as high performance, low debt ratio, large firm size, extra funds (e.g., an increase in long-term liabilities and paid-in capital increases), and cross-listings in more than two countries (Hung, Subramanyam 2007; Harris, Muller 1999). By using all these variables except cross-listing, we construct Model 1 as follows:

[Model 1]

$$
\begin{aligned}
& I F R S_{i t}=\alpha_{0}+\alpha_{1} R O A_{i t}+\alpha_{2} L E V_{i t}+\alpha_{3} P P E_{i t}+\alpha_{4} S I Z E_{i t}+ \\
& \alpha_{5} L_{-} D E B T_{i t}+\alpha_{6} \mathrm{SUB}_{i t}+\alpha_{7} I P O_{i t}+\varepsilon_{i t},
\end{aligned}
$$

where $I F R S_{i t}$ : Dummy variable that equals 1 if firm $i$ adopts IFRS in year $t$ and 0 otherwise. $R O A_{i t}$ : Return on assets of firm $i$ in year $t$ (Earnings before Tax/Total Assets). $L E V_{i t}$ : Debt ratio of firm $i$ in year $t$ (Total Debt/Total Assets). $P P E_{i t}:$ Fixed asset ratio of firm $i$ in year $t$ (Property, plant, and equipment/Total Assets). SIZE $E_{i t}$ : Natural $\log$ of assets of firm $i$ in year $t$. $L_{-} D E B T_{i t}$ : Dummy variable that equals 1 if the long-term liabilities of firm $i$ increase in year $t$ and 0 otherwise. $S U B_{i t}$ : Dummy variable that equals 1 if firm $i$ is included in the 30 largest business groups in year $t$ and 0 otherwise. $I P O_{i t}$ : Dummy variable that equals 1 if firm $i$ in year $t$ is pre-IPO and 0 otherwise.

This step is a necessary proactive process to examine the sample population in this study. In other words, this process ensures that the results are free from sample selection bias by excluding the characteristics of those firms that adopted IFRS voluntarily in order to verify the effectiveness of IFRS adoption.

\subsection{Changes in the earnings quality of unlisted firms after adopting IFRS}

The results of previous studies of IFRS adoption and earnings quality depend on the countries, industries and firms analysed (Cuijpers, Buijink 2005; Gassen, Sellhorn 2006; Covrig et al. 2007). However, by expanding the scope of these studies and using capital book value as a proxy for earnings quality, Barth et al. (2008) found that those firms that adopted IFRS had higher earnings quality than those that did not, after analysing earnings management, timely loss recognition and the value coherence of accounting earnings. Further, Kim (2011) showed that the earnings quality of those listed firms that had adopted IFRS early improved thereafter. In this context, we contend that the earnings quality of unlisted firms rises after the voluntary adoption of IFRS, leading to the formulation of the following two hypotheses:

H1-1: Ceteris paribus, the earnings quality of unlisted firms that adopt IFRS is higher than that of unlisted firms that adopt KGAAP;

H1-2: Ceteris paribus, after adopting IFRS the earnings quality of unlisted firms is higher than before IFRS adoption. 
In methodological terms, this study uses Heckman's (1979) two-stage model in order to remove sample selection bias. We therefore examine the effectiveness of voluntary IFRS adoption by unlisted firms after controlling for the factors that drive its adoption, as confirmed in Section 2.1. We then analyse changes in earnings quality after adoption and compare earnings quality with that of firms using KGAAP.

[Model 2]

Stage 1: [Model 1] from 2.1.

Stage 2:

$$
\begin{aligned}
& D A(\text { Discretionary Accruals })_{i t}=\beta_{0}+\beta_{1} I F R S_{i t}\left(\text { or Post_IFRS } S_{i t}\right)+\beta_{2} S_{\text {IZE }} \text { it }+ \\
& \beta_{3} R O A_{i t}+\beta_{4} L E V_{i t}+\beta_{5} B I G 4_{i t}+\beta_{6} \text { Mills }_{i t}+\sum I_{-} D u m_{i t}+\sum Y_{-} D u m_{i t}+\varepsilon_{i t} \text {, }
\end{aligned}
$$

where $D A_{i t}$ : Discretionary accruals of firm $i$ in year $t$ estimated by the modified Jones model. IFRS $S_{i t}$ : Dummy variable that equals 1 if firm $i$ adopts IFRS in year $t$ and 0 otherwise. Post_IFRS it : Dummy variable that equals 1 if firm $i$ adopts IFRS after year $t$ and 0 otherwise. $B I G 4_{i t}$ : Dummy variable that equals 1 if the firm's auditor belongs to the Big4 auditors and 0 otherwise. Mills $s_{i t}$ : Inverse Mills Ratio from the first stage of Model 1. $\Sigma I_{-}$Dum $_{i t}$ : Industry dummy. $\Sigma Y \_$Dum $_{i t}$ : Year dummy.

We use cross-sectional analysis by industry and year in order to estimate discretionary accruals. The modified Jones model (Kothari et al. 2005) is as follows. Discretionary accruals are the residuals $\left(\varepsilon_{i t}\right)$ calculated using the equation:

$$
T A_{i t}=\alpha_{0} \frac{1}{A_{i t-1}}+\alpha_{1} \frac{\Delta R E V_{i t}-\Delta R E C_{i t}}{A_{i t-1}}+\alpha_{2} \frac{P P E_{i t}}{A_{i t-1}}+\varepsilon_{i t},
$$

where $T A_{i t}$ : Total accruals of firm $i$ in year $t$ (Net income - Operating cash flow). $A_{i t-1}$ : Total assets of firm $i$ in year $t-1 . \Delta R E V_{i t}$ : Changes in the sales of firm $i$ in year $t$ $\left(\right.$ Sales $_{t}-$ Sales $\left._{t-1}\right) . \triangle R E C_{i t}$ : Changes in the receivables of firm $i$ in year $t$ (Receivables $_{t}-$ Receivables $\left._{t-1}\right) \cdot P P E_{i t}$ : Property, plant, and equipment of firm $i$ in year $t$ (except land and construction).

\subsection{Changes in the cost of debt of unlisted firms after adopting IFRS}

Leuz and Verrecchia's (2000) study of German firms found that firms which adopt IFRS or USGAAP benefited from a decrease in asymmetric information compared with those that implemented German accounting standards, which then resulted in a decreased cost of debt. Similarly, Daske et al. (2008) showed that increased information asymmetry affects the cost of capital and firm value. These authors also reported that IFRS adoption increases market liquidity, decreases the cost of capital and increases firm value. In particular, voluntary IFRS adopters had a far greater influence on the capital market than firms that adopted these standards mandatorily. Moreover, previous studies have consistently shown that IFRS adoption improves disclosure standards, thereby decreasing the cost of capital, with voluntary adopters showing even greater decreases in this regard. Further, Yang, Lee and Yoon (2011) reported that if accounting disclosure was expanded and its quality improved, asymmetric information could be decreased further, which could serve as a low risk premium, resulting in a decreased 
cost of debt. Market information on unlisted firms can be limited, however, implying a high information risk. In this case, if unlisted firms adopt IFRS voluntarily and increase the quality of accounting disclosure, information asymmetry will reduce, as will the cost of debt in the long run, leading to the next two hypotheses:

H2-1: Ceteris paribus, the cost of debt for unlisted firms that adopt IFRS is less than that for unlisted firms that adopt K-GAAP;

H2-2: Ceteris paribus, the cost of debt for unlisted firms after adopting IFRS is lower than that before IFRS adoption.

[Model 3]

Stage 1: [Model 1] from 2.1.

Stage 2:

$$
\begin{aligned}
& C_{-} \text {DEBT }(\text { Costof Debt })_{j i t}=\beta_{0}+\beta_{1} I F R S_{i t}(\text { or Post_IFRS } \\
& \text { it })+\beta_{2} \text { SIZE }_{i t}+ \\
& \beta_{3} R O A_{i t}+\beta_{4} L E V_{i t}+\beta_{5} P P E_{i t}+\beta_{6} G R W_{i t}+\beta_{7} N E G E_{i t}+\beta_{8} \text { Mills }_{i t}+ \\
& \sum I_{\text {Dumit }}+\sum Y_{\text {Dumit }}+\varepsilon_{i t},
\end{aligned}
$$

where $C_{-} D E B T_{1 i t}$ : Interest rate of firm $i$ in year $t$ (Interest expenses/Average debt). $C_{-} D E B T_{2 i t}$ : Fractional rank variable based on $C_{-} D E B T_{1}$ of firm $i$ in year $t$ (five groups). $P P E_{i t}$ : Fixed asset ratio of firm $i$ in year $t$ (Property, plant, and equipment/Total Assets). $G R W_{i t}$ : Growth rate of firm $i$ in year $t$ (Change in sales/Opening assets). $N E G E_{i t}$ : Dummy variable that equals 1 if the firm's total equity is below its capital and 0 otherwise.

In Model 3, the principal variable is interest rate $\left(C_{-} D E B T_{1}\right)$, which is calculated as aggregated interest expenses in year $t$ divided by average short- and long-term debt at the beginning and end of each fiscal year (Pittman, Fortin 2004; Francis et al. 2005a, $2005 b)$. Rank variable based on the interest rate $\left(C_{-} D E B T_{2}\right)$ is used to alleviate the effects of extreme observation that continuous variable might have (Francis et al. 2004, 2005a; Kim, Sohn 2009). These also generalize the main results. The control variables are those reported as determining factors in the cost of capital by previous studies and those that characterise unlisted firms (Khurana, Raman 2004; Pittman, Fortin 2004; Ahmed et al. 2008; Fernando et al. 2008; Dhaliwal et al. 2008; Lou, Vasvari 2009; Hope et al. 2009; Kim, Park 2010; McInnis 2010; Ge, Kim 2010; Kim et al. 2011).

\subsection{Sample selection}

We selected firms unlisted on the Korean stock exchange from 2009 to 2011. We excluded financial institutions because of their different accounting rules and materials compared with nonfinancial industries. Further, we restricted the sample to firms having a fiscal year ending in December for comparability purposes, and also excluded the top and bottom $1 \%$ of firms from the final sample. Panel $A$ of Table 1 shows the sample selection process, while Panel $B$ and Panel $C$ indicate the sample distribution by time and industry. Our final sample comprised 33,869 firm-year observations. We collected financial data through TS-2000 and KIS-VALUE III $^{2}$. We ran cross-sectional pooled

\footnotetext{
2 Total Solution 2000 by Korea Companies Information and KIS-VALUE III at NICE Information Service.
} 
regressions with OLS and complimentary reported the estimates from firm-fixed effect models, as discussed in the sensitivity analysis section. In addition, because the present study aims to verify unlisted firms empirically, this analysis can be affected by cluster or cross-sectional dependence between firms. In this case, the $t$ value of the regression coefficients can be shown to be bigger than their actual values, thereby exaggerating the result (Petersen 2009). Therefore, adding clustering verification and ascertaining consistent results from the OLS regression analysis can add robustness to the results.

Table 1. Sample selection

Panel A: Process of sample selection

\begin{tabular}{lcccc}
\hline Unlisted firms (fiscal year ending in December) & 2009 & 2010 & 2011 & Total \\
\cline { 2 - 5 } & 17,172 & 18,357 & 16,781 & 52,310 \\
\hline Missing data on financial variables & $(6,077)$ & $(6,480)$ & $(4,369)$ & $(16,926)$ \\
\hline Financial institutions & $(3)$ & $(3)$ & $(5)$ & $(11)$ \\
\hline Extremes* & $(473)$ & $(503)$ & $(528)$ & $(1,504)$ \\
\hline Final sample & 10,619 & 11,371 & 11,879 & 33,869 \\
\hline
\end{tabular}

Panel B: Time distribution

\begin{tabular}{cccc}
\hline Year & Frequency & $\%$ & Cumulative $\%$ \\
\hline 2009 & 10,619 & 31.35 & 31.35 \\
\hline 2010 & 11,371 & 33.57 & 64.92 \\
\hline 2011 & 11,879 & 35.08 & 100 \\
\hline Total & 33,869 & 100 & \\
\hline
\end{tabular}

Panel C: Industry distribution

\begin{tabular}{lcccc}
\hline Industry & Frequency & $\%$ & Cum. frequency & Cumulative \% \\
\hline Manufacturing & 19,099 & 56.39 & 19,099 & 56.39 \\
\hline Construction & 3,199 & 9.45 & 22,298 & 65.84 \\
\hline Wholesale and retail & 4,490 & 13.26 & 26,788 & 79.09 \\
\hline Transportation & 739 & 2.18 & 27,527 & 81.27 \\
\hline Real estate and leasing & 1,985 & 5.86 & 29,512 & 87.14 \\
\hline Service & 4,115 & 12.15 & 33,627 & 99.29 \\
\hline Others & 242 & 0.71 & 33,869 & 100 \\
\hline Total & 33,869 & 100 & & \\
\hline
\end{tabular}

Notes: Industry classification is based on the one-digit classification in KIS-VALUE III of the NICE Group (National Information and Credit Evaluation Inc.). *We deleted the top and bottom $1 \%$ of the samples as extremes.

Panel $A$ of Table 1 shows that manufacturing accounts for approximately $56 \%$ of the sample, indicating that most of the firms that form the backbone of Korea's manufacturing industry are unlisted. 


\section{Empirical results}

\subsection{Descriptive statistics}

Table 2 reports the descriptive statistics of the variables used in the present study. $D A$ in Panel $A$ is the variable that represents earnings quality, and its mean and median values are -0.006 and -0.001 , respectively. During the period, the interest rate $\left(C_{-} D E B T_{1}\right)$ of each firm is approximately $6.1 \%$ on average. Panel $B$ divides the sample into five groups according to the size of the interest rate $\left(C_{-} D E B T_{1}\right)$. The highest average interest rate is approximately $9.9 \%$, while the interest rates of the firms that adopt IFRS and KGAAP are $5.9 \%$ and $6.1 \%$, respectively $($ Panel $C)$. Less than $1 \%(\mathrm{n}=265)$ of the unlisted firms in our sample are defined herein as large businesses $(S U B=0.00782)$.

Table 2. Descriptive statistics

Panel A: Full sample

\begin{tabular}{lccccc}
\hline Total sample $(N=33,869)$ & Mean & Std. dev & 1Q & Median & 3Q \\
\hline$D A$ & 0.0061 & 0.1454 & -0.0567 & 0.0041 & 0.0641 \\
\hline$C \_D E B T_{1}$ & 0.0250 & 0.0262 & 0.0092 & 0.0234 & 0.0379 \\
\hline$I F R S$ & 0.0225 & 0.1483 & 0.0000 & 0.0000 & 0.0000 \\
\hline$S I Z E$ & 17.04 & 0.7958 & 16.46 & 16.83 & 17.42 \\
\hline$R O A$ & 0.0273 & 0.1132 & 0.0046 & 0.0273 & 0.0676 \\
\hline$L E V$ & 0.6613 & 0.4523 & 0.5035 & 0.6698 & 0.8052 \\
\hline$P P E$ & 0.2108 & 0.1823 & 0.0723 & 0.1677 & 0.2996 \\
\hline$G R W$ & 0.1569 & 0.5642 & -0.0360 & 0.0796 & 0.3072 \\
\hline
\end{tabular}

Panel B: Group sample by fractional rank variable $\left(C_{-} D E B T_{2}\right)$

\begin{tabular}{lccccc}
\hline & Group 1 & Group 2 & Group 3 & Group 4 & Group 5 \\
\hline$D A$ & Mean & Mean & Mean & Mean & Mean \\
\hline$C \_D E B T_{1}$ & 0.0086 & 0.0065 & 0.0085 & 0.0043 & 0.0025 \\
\hline$I F R S$ & -0.0076 & 0.0125 & 0.0233 & 0.0342 & 0.0628 \\
\hline$S I Z E$ & 0.0283 & 0.0256 & 0.0202 & 0.0186 & 0.0197 \\
\hline$R O A$ & 17.06 & 17.05 & 17.02 & 17.01 & 17.02 \\
\hline$L E V$ & 0.0404 & 0.0328 & 0.0255 & 0.0200 & 0.0177 \\
\hline$P P E$ & 0.6155 & 0.6247 & 0.6802 & 0.6966 & 0.6893 \\
\hline$G R W$ & 0.2123 & 0.2352 & 0.2235 & 0.2130 & 0.1698 \\
\hline$N E G E$ & 0.1584 & 0.1565 & 0.1609 & 0.1686 & 0.1398 \\
\hline$B I G 4$ & 0.1522 & 0.1009 & 0.1079 & 0.1218 & 0.1345 \\
\hline$L \_D E B T$ & 0.1771 & 0.1663 & 0.1634 & 0.1484 & 0.1448 \\
\hline$S U B$ & 0.4850 & 0.4897 & 0.4809 & 0.4747 & 0.4753 \\
\hline$N$ & 0.0093 & 0.0068 & 0.0066 & 0.0081 & 0.0061 \\
\hline
\end{tabular}


End of Table 2

Panel C: IFRS firms vs. KGAAP firms

\begin{tabular}{lcccc}
\hline \multicolumn{1}{c}{ Variables } & IFRS & KGAAP & Difference & $t$-value \\
\hline$D A$ & -0.012 & -0.006 & -0.006 & -1.28 \\
\hline$C \_D E B T_{1}$ & 0.059 & 0.061 & -0.002 & $-2.34^{* *}$ \\
\hline$S I Z E$ & 17.92 & 17.03 & 0.887 & $23.94^{* * *}$ \\
\hline$R O A$ & 0.035 & 0.015 & 0.020 & $4.30^{* * *}$ \\
\hline$L E V$ & 0.586 & 0.693 & -0.107 & $-9.67^{* * *}$ \\
\hline$P P E$ & 0.242 & 0.206 & 0.036 & $4.57^{* * *}$ \\
\hline$G R W$ & 0.255 & 0.114 & 0.141 & $6.22^{* * *}$ \\
\hline$N E G E$ & 0.166 & 0.177 & -0.010 & -0.74 \\
\hline$B I G 4$ & 0.717 & 0.170 & 0.547 & $32.52^{* * *}$ \\
\hline$L \_D E B T$ & 0.599 & 0.453 & 0.146 & $7.93^{* * *}$ \\
\hline$S U B$ & 0.058 & 0.007 & 0.051 & $5.89^{* * *}$ \\
\hline$N$ & 728 & 33,141 & & \\
\hline
\end{tabular}

Panel D: Pre- and post-IFRS adoption

\begin{tabular}{lcccc}
\hline Variables & Pre-IFRS & Post-IFRS & Difference & $t$-value \\
\hline$D A$ & -0.003 & -0.012 & -0.009 & -1.29 \\
\hline$C \_D E B T_{1}$ & 0.064 & 0.057 & -0.007 & $-4.79^{* * *}$ \\
\hline$S I Z E$ & 17.752 & 17.915 & 0.163 & $3.51^{* * *}$ \\
\hline$R O A$ & 0.036 & 0.034 & -0.001 & -0.21 \\
\hline$L E V$ & 0.590 & 0.586 & -0.004 & -0.30 \\
\hline$P P E$ & 0.236 & 0.242 & 0.005 & 0.56 \\
\hline$G R W$ & 0.235 & 0.255 & 0.019 & 0.70 \\
\hline$N E G E$ & 0.183 & 0.166 & -0.016 & -0.93 \\
\hline$B I G 4$ & 0.608 & 0.717 & 0.109 & $5.02^{* * *}$ \\
\hline$N$ & 1,221 & 728 & & \\
\hline$N$
\end{tabular}

Notes: $D A$ : Discretionary accruals estimated using the modified Jones model, $C_{-} D E B T_{1}$ : Interest rate (Interest expenses/Average debt), $C_{-} D E B T_{2}$ : Fractional rank variable based on $C_{-} D E B T_{1}, S I Z E$ : Natural log of assets, ROA: Return on assets, $L E V$ : Debt ratio, PPE: Fixed asset ratio (Property, plant, and equipment/Total Assets), GRW: Growth rate (Change in sales/Opening assets), $N E G E$ : Dummy variable that equals 1 if a firm has impaired capital and 0 otherwise, BIG4: Dummy variable that equals 1 if the firm's auditor belongs to the Big4 auditors and 0 otherwise, $L \_D E B T$ : Dummy variable that equals 1 if long-term liabilities increase and 0 otherwise, $S U B$ : Dummy variable that equals 1 if a firm is included in the 30 largest business groups and 0 otherwise.

Moreover, these unlisted firms file consolidated financial statements with their listed parent firms; it is therefore likely that they adopted IFRS voluntarily because their parent firms adopted IFRS mandatorily.

In Panel $C$,We find that IFRS and non-IFRS firms show significant differences in most variables. IFRS firms show significantly lower interest rates $\left(C_{-} D E B T_{1}\right)$ at the $1 \%$ level 
as well as higher values in terms of firm size $(S I Z E)$, return on assets $(R O A)$, fixed asset ratio $(P P E)$, and growth rate $(G R W)$ compared with non-IFRS firms. We also find that interest rates $\left(C_{-} D E B T_{1}\right)$ post-adoption are lower than during the pre-adoption period (Panel D). Table 3 shows the correlations among the variables. IFRS adoption and earnings quality show a negative correlation $(-0.006$; not significant), while IFRS adoption and interest rate have a significant negative correlation $(-0.01,5 \%$ level $)$. IFRS adoption also shows positive correlations with firm size $(S I Z E)$, return on assets $(R O A)$, fixed asset ratio $(P P E)$ and growth rate $(G R W)$ all at the $1 \%$ significance level.

Table 3. Correlations

\begin{tabular}{|c|c|c|c|c|c|c|c|c|c|}
\hline & IFRS & $D A$ & $C_{-} D E B T_{1}$ & SIZE & $R O A$ & $L E V$ & $P P E$ & $G R W$ & $N E G E$ \\
\hline IFRS & & -0.006 & $-0.01^{* *}$ & $0.15^{\dagger}$ & $0.02^{\dagger}$ & $-0.04^{\dagger}$ & $0.027^{\dagger}$ & $0.03^{\dagger}$ & -0.004 \\
\hline$D A$ & & & $-0.03^{\dagger}$ & $0.05^{\dagger}$ & $0.41^{\dagger}$ & $-0.20^{\dagger}$ & $-0.02^{\dagger}$ & $0.07^{\dagger}$ & $-0.17^{\dagger}$ \\
\hline$C_{-} D E B T_{1}$ & & & & $-0.04^{\dagger}$ & $-0.03^{\dagger}$ & $0.03^{\dagger}$ & $0.017^{\dagger}$ & $-0.03^{\dagger}$ & $0.04^{\dagger}$ \\
\hline SIZE & & & & & $0.12^{\dagger}$ & $-0.12^{\dagger}$ & $-0.03^{\dagger}$ & $0.08^{\dagger}$ & $-0.12^{\dagger}$ \\
\hline$R O A$ & & & & & & $-0.45^{\dagger}$ & $-0.09^{\dagger}$ & $0.19^{\dagger}$ & $-0.36^{\dagger}$ \\
\hline$L E V$ & & & & & & & $0.13^{\dagger}$ & $-0.05^{\dagger}$ & $0.51^{\dagger}$ \\
\hline$P P E$ & & & & & & & & $-0.02^{\dagger}$ & $0.20^{\dagger}$ \\
\hline$G R W$ & & & & & & & & & $-0.07^{\dagger}$ \\
\hline
\end{tabular}

$N E G E$

Notes: $*, * *$ and ${ }^{\dagger}$ indicate the $10 \%, 5 \%$ and $1 \%$ level of significance in two-tailed tests, respectively. See Table 2 for the definition of the variables.

\subsection{Results of IFRS vs KGAAP}

Table 4 presents the results obtained from testing H1, namely whether earnings quality and the cost of debt of unlisted firms that adopt IFRS is higher or lower, respectively, than those of unlisted KGAAP firms. Panel $A$ of Table 4 reports the driving factors behind voluntary IFRS adoption from the first stage results of Heckman's two-stage approach. The panel shows that all variables except return on assets $(R O A)$ and initial public offering $(I P O)$ influence unlisted firms to adopt IFRS voluntarily. In other words, firms that have lower debt ratios, higher fixed asset ratios and larger sizes are more likely to adopt IFRS voluntarily. Further, because long-term liabilities ( $\left.L_{-} D E B T\right)$ play an important role in adopting IFRS voluntarily, we can assume that bond issue and longterm debt procurement are other motivating factors. Finally, if the firm is a subsidiary of a large business $(S U B)$, it is also more likely to adopt IFRS. Next, Panel B presents the results of the empirical analysis after controlling for the characteristics of IFRS adopters confirmed in stage 1 . The first column shows the results in terms of changes in earnings quality, while the second and third columns show the changes in the cost of debt using interest rate and fractional rank of interest rate. The correlation between IFRS adoption and earnings quality $(D A)$ is significantly negative $(-0.012$ at the $5 \%$ level). This finding 
implies that firms adopting IFRS have higher earnings quality than KGAAP firms ${ }^{3}$. The results for the remaining control variables are consistent with those of previous studies (Xie et al. 2003; Defond, Jiambalvo 1994; Dechow et al. 1995; Becker et al. 1998; Yoon 1998; Choi, Choe 2003; Francis, Krishnan 1999). That is, earnings quality ( $D A$ ) is higher (lower) for a bigger size, a lower return on assets, lower leverage, and in the big 4. Overall, the results are consistent with prior research findings that suggest that the adoption of IFRS is associated with higher earnings quality, and H1-1 is supported (e.g., Ashbaugh, Pincus 2001; Barth et al. 2008; Gordon et al. 2009). The cost of debt is not significantly correlated with IFRS adoption when using interest rate ${ }^{4}$ as a proxy, but it does show a significantly negative correlation with IFRS adoption when using the fractional rank variable $(0.183$ at the $1 \%$ significance level). This finding suggests that unlisted firms which adopt IFRS voluntarily have a lower cost of debt than KGAAP firms. In other words, the voluntary adoption of IFRS in unlisted firms shows the same effects as mandatory adoption in terms of capital market benefits (Daske et al. 2008; Hail et al. 2010; Leuz, Verrecchia 2000). Thus, H2-1 is supported.

Table 4. Regression analysis

Panel A: First stage: Probit model

\begin{tabular}{lcccc}
\hline & \multicolumn{5}{c}{ Dep.V } & \multicolumn{4}{c}{ IFRS } \\
\cline { 2 - 5 } Indep.V & Coefficient & Wald Chi-square & Pr $>$ ChiSq & Standardised Estimate \\
\hline Intercept & -8.558 & 729.8 & $<.0001$ & \\
\hline ROA & -0.178 & 1.153 & 0.283 & -0.029 \\
\hline LEV & -0.417 & 34.94 & $<.0001$ & -0.179 \\
\hline$P P E$ & 0.280 & 9.619 & 0.0019 & 0.054 \\
\hline SIZE & 0.394 & 501.7 & $<.0001$ & 0.330 \\
\hline L_DEBT & 0.189 & 31.67 & $<.0001$ & 0.094 \\
\hline SUB & 0.335 & 10.69 & 0.0011 & 0.030 \\
\hline IPO & -1.653 & 0.001 & 0.9781 & -0.009 \\
\hline Likelihood Ratio & & & $876.90^{* * *}$ & \\
\hline-2 Log L & & & 7031 & \\
\hline$N$ & & & 33,869 & \\
\hline
\end{tabular}

Notes: IFRS: Dummy variable that equals 1 if a firm adopts IFRS and 0 otherwise, IPO: Dummy variable that equals 1 if year $t$ is pre-IPO and 0 otherwise. See Table 2 for the definition of the other variables.

\footnotetext{
${ }^{3}$ The lower value of $D A$ means higher earnings quality.

${ }^{4} \mathrm{We}$ also alternatively use an interest rate spread calculated as the difference between the interest rate on each firm's debt and the national and public bond interest rate with the same expiration. This proxy represents the additional interest rate that firms must pay additionally to the interest rate for their loans. The results are qualitatively similar.
} 
End of Table 4

Panel B: Second stage: OLS regression results of IFRS firms vs. non-IFRS firms and OLS regression results of IFRS firms after IFRS adoption

\begin{tabular}{|c|c|c|c|c|c|c|}
\hline \multirow{3}{*}{ Indep. $\mathrm{V}$} & \multicolumn{3}{|c|}{ IFRS firms vs. non-IFRS firms } & \multicolumn{3}{|c|}{ IFRS firms after IFRS adoption } \\
\hline & $D A$ & $C_{-} D E B T_{1}$ & $C_{-} D E B T_{2}$ & $D A$ & $C_{-} D E B T_{1}$ & $C_{-} D E B T_{2}$ \\
\hline & \multicolumn{3}{|c|}{ Coefficient (t-statistics) } & \multicolumn{3}{|c|}{ Coefficient (t-statistics) } \\
\hline Intercept & $\begin{array}{c}0.361 \\
\left(5.33^{* * *}\right)\end{array}$ & $\begin{array}{c}-0.099 \\
\left(-1.98^{* *}\right)\end{array}$ & $\begin{array}{c}-4.886 \\
\left(-6.88^{* * *}\right)\end{array}$ & $\begin{array}{c}-0.518 \\
\left(-1.77^{*}\right)\end{array}$ & $\begin{array}{l}-0.008 \\
(-0.18)\end{array}$ & $\begin{array}{l}3.598 \\
(1.43)\end{array}$ \\
\hline IFRS & $\begin{array}{c}-0.012 \\
\left(-2.05^{* *}\right)\end{array}$ & $\begin{array}{l}-0.001 \\
(-0.27)\end{array}$ & $\begin{array}{c}-0.183 \\
\left(-3.52^{* * *}\right)\end{array}$ & & & \\
\hline Post_IFRS & & & & $\begin{array}{l}-0.015 \\
(-0.71)\end{array}$ & $\begin{array}{c}-0.006 \\
\left(-1.84^{*}\right)\end{array}$ & $\begin{array}{c}-0.417 \\
\left(-2.40^{* *}\right)\end{array}$ \\
\hline SIZE & $\begin{array}{c}-0.015 \\
\left(-5.08^{* * *}\right)\end{array}$ & $\begin{array}{c}0.005 \\
\left(2.07^{* *}\right)\end{array}$ & $\begin{array}{c}0.276 \\
\left(8.77^{* * *}\right)\end{array}$ & $\begin{array}{c}0.025 \\
\left(1.88^{*}\right)\end{array}$ & $\begin{array}{l}0.001 \\
(0.33)\end{array}$ & $\begin{array}{l}-0.093 \\
(-0.84)\end{array}$ \\
\hline$R O A$ & $\begin{array}{c}0.411 \\
\left(72.53^{* * *}\right)\end{array}$ & $\begin{array}{c}-0.012 \\
\left(-3.18^{* * *}\right)\end{array}$ & $\begin{array}{c}-0.897 \\
\left(-16.3^{* * *}\right)\end{array}$ & $\begin{array}{c}0.135 \\
\left(3.91^{* * *}\right)\end{array}$ & $\begin{array}{c}-0.023 \\
\left(-4.55^{* * *}\right)\end{array}$ & $\begin{array}{c}-1.465 \\
\left(-5.07^{* * *}\right)\end{array}$ \\
\hline$L E V$ & $\begin{array}{c}0.017 \\
\left(4.66^{* * *}\right)\end{array}$ & $\begin{array}{c}0.008 \\
\left(2.83^{* * *}\right)\end{array}$ & $\begin{array}{c}0.142 \\
\left(3.66^{* * *}\right)\end{array}$ & $\begin{array}{c}-0.034 \\
\left(-1.86^{*}\right)\end{array}$ & $\begin{array}{l}-0.001 \\
(-0.50)\end{array}$ & $\begin{array}{c}0.533 \\
\left(3.26^{* * *}\right)\end{array}$ \\
\hline$B I G 4$ & $\begin{array}{c}-0.016 \\
\left(-7.29^{* * *}\right)\end{array}$ & & & $\begin{array}{c}-0.015 \\
\left(-1.94^{*}\right)\end{array}$ & & \\
\hline$P P E$ & & $\begin{array}{c}0.009 \\
\left(2.78^{* * *}\right)\end{array}$ & $\begin{array}{c}1.108 \\
\left(24.19^{* * *}\right)\end{array}$ & & $\begin{array}{c}0.023 \\
\left(8.06^{* * *}\right)\end{array}$ & $\begin{array}{c}1.600 \\
\left(9.83^{* * *}\right)\end{array}$ \\
\hline$G R W$ & & $\begin{array}{c}-0.002 \\
\left(-2.75^{* * *}\right)\end{array}$ & $\begin{array}{c}-0.149 \\
\left(-11.8^{* * *}\right)\end{array}$ & & $\begin{array}{c}-0.004 \\
\left(-4.12^{* * *}\right)\end{array}$ & $\begin{array}{c}-0.236 \\
\left(-4.61^{* * *}\right)\end{array}$ \\
\hline$N E G E$ & & $\begin{array}{c}0.005 \\
\left(3.32^{* * *}\right)\end{array}$ & $\begin{array}{c}0.148 \\
\left(6.33^{* * *}\right)\end{array}$ & & $\begin{array}{c}0.005 \\
\left(3.28^{* * *}\right)\end{array}$ & $\begin{array}{c}0.182 \\
\left(1.92^{*}\right)\end{array}$ \\
\hline Mills & $\begin{array}{c}-0.054 \\
\left(-6.73^{* * *}\right)\end{array}$ & $\begin{array}{c}0.024 \\
\left(4.08^{* * *}\right)\end{array}$ & $\begin{array}{c}1.265 \\
\left(15.17^{* * *}\right)\end{array}$ & $\begin{array}{l}0.048 \\
(1.43)\end{array}$ & $\begin{array}{c}0.012 \\
\left(2.47^{* *}\right)\end{array}$ & $\begin{array}{l}0.312 \\
(1.08)\end{array}$ \\
\hline I_Dum & & Included & & & Included & \\
\hline Y_Dum & & Included & & & Included & \\
\hline $\operatorname{Adj} R-S q$ & 0.179 & 0.004 & 0.094 & 0.023 & 0.129 & 0.178 \\
\hline$F$ Value & $570.57^{* * *}$ & $10.94^{* * *}$ & $237.7^{* * *}$ & $4.47^{* * *}$ & $20.22^{* * *}$ & $29.09^{* * *}$ \\
\hline$N$ & & 33,869 & & & 1,949 & \\
\hline
\end{tabular}

Notes: Post_IFRS $S_{i t}$ : Dummy variable that equals 1 if firm $i$ adopts IFRS after year $t$ and 0 otherwise. See Table 2 for the definition of the other variables. Mills $s_{i t}$ : Inverse Mills Ratio from the first stage of Model 1, I_Dum: Industry dummy variables, Y_Dum: Year dummy variables. See Table 2 for the definition of the other variables.

\subsection{Results of pre and post IFRS}

Table 5 presents the changes in earnings quality and the cost of debt for IFRS firms before and after adoption after controlling for the characteristics of IFRS adopters in Panel $A$ of Table 4. Earnings quality $(D A)$ shows no significant differences between preand post-adoption $(-0.015)$, whereas the cost of debt decreases significantly after IFRS 
adoption. Interest rate also shows marginal decrease at the $10 \%$ level, and the result using the fractional rank variables shows significant decreases at the 5\% level $(-0.417)$. This is consistent with the findings of previous studies that IFRS grants managers a significant amount of discretion in their application, and as a result the earnings quality that results from the new standards either shows no improvement or is lower than before (e.g., Christensen et al. 2008; Capkun et al. 2011). Nevertheless the cost of debt is still affected by IFRS adoption, being generally reduced (Daske et al. 2008; Hail et al. 2010; Leuz, Verrecchia 2000). Therefore, when unlisted firms are sensitive to the cost of debt as their main source of funds, voluntarily IFRS adoption decreases the interest rate, which reduces the cost of debt. Thus, H1-2 is rejected and H2-2 is supported.

Table 5. OLS regression results of IFRS firms after IFRS adoption

\begin{tabular}{|c|c|c|c|}
\hline Dep.V & $D A$ & $C_{-} D E B T_{1}$ & $C_{-} D E B T_{2}$ \\
\hline Indep.V & \multicolumn{3}{|c|}{ Coefficient (t-statistics) } \\
\hline Intercept & $\begin{array}{c}-0.518 \\
\left(-1.77^{*}\right)\end{array}$ & $\begin{array}{c}-0.008 \\
(-0.18)\end{array}$ & $\begin{array}{l}3.598 \\
(1.43)\end{array}$ \\
\hline Post_IFRS & $\begin{array}{l}-0.015 \\
(-0.71)\end{array}$ & $\begin{array}{l}-0.006 \\
\left(-1.84^{*}\right)\end{array}$ & $\begin{array}{c}-0.417 \\
\left(-2.40^{* *}\right)\end{array}$ \\
\hline SIZE & $\begin{array}{c}0.025 \\
\left(1.88^{*}\right)\end{array}$ & $\begin{array}{l}0.001 \\
(0.33)\end{array}$ & $\begin{array}{l}-0.093 \\
(-0.84)\end{array}$ \\
\hline$R O A$ & $\begin{array}{c}0.135 \\
\left(3.91^{* * *}\right)\end{array}$ & $\begin{array}{c}-0.023 \\
\left(-4.55^{* * *}\right)\end{array}$ & $\begin{array}{c}-1.465 \\
\left(-5.07^{* * *}\right)\end{array}$ \\
\hline$L E V$ & $\begin{array}{c}-0.034 \\
\left(-1.86^{*}\right)\end{array}$ & $\begin{array}{c}-0.001 \\
(-0.50)\end{array}$ & $\begin{array}{c}0.533 \\
\left(3.26^{* * *}\right)\end{array}$ \\
\hline BIG4 & $\begin{array}{c}-0.015 \\
\left(-1.94^{*}\right)\end{array}$ & & \\
\hline$P P E$ & & $\begin{array}{c}0.023 \\
\left(8.06^{* * *}\right)\end{array}$ & $\begin{array}{c}1.600 \\
\left(9.83^{* * *}\right)\end{array}$ \\
\hline$G R W$ & & $\begin{array}{c}-0.004 \\
\left(-4.12^{* * *}\right)\end{array}$ & $\begin{array}{c}-0.236 \\
\left(-4.61^{* * *}\right)\end{array}$ \\
\hline$N E G E$ & & $\begin{array}{c}0.005 \\
\left(3.28^{* * *}\right)\end{array}$ & $\begin{array}{c}0.182 \\
\left(1.92^{*}\right)\end{array}$ \\
\hline Mills & $\begin{array}{l}0.048 \\
(1.43) \\
\end{array}$ & $\begin{array}{c}0.012 \\
\left(2.47^{* *}\right) \\
\end{array}$ & $\begin{array}{l}0.312 \\
(1.08)\end{array}$ \\
\hline I_Dum & & Included & \\
\hline Y_Dum & & Included & \\
\hline $\operatorname{Adj} R-S q$ & 0.023 & 0.129 & 0.178 \\
\hline$F$ Value & $4.47^{* * *}$ & $20.22^{* * *}$ & $29.09^{* * *}$ \\
\hline$N$ & & 1,949 & \\
\hline
\end{tabular}

Notes: Post_IFRS it: Dummy variable that equals 1 if firm $i$ adopts IFRS after year $t$ and 0 otherwise. See Table 2 for the definition of the other variables. 
The financial data on the sampled unlisted firms in this study may suffer from a firmlevel clustering problem and we adjusted the OLS standard errors by firm-level cluster in order to check the robustness of our results. In an untabulated analysis, we found the results considering clustering are qualitatively similar to the main results, confirming that our results are not biased by clustering. Also we tested the sensitivity of our results to an econometric model which uses firm-level unbalanced panel data ${ }^{5}$. We re-estimated the cross-sectional analysis using firm-fixed effects and eliminated time-invariant unobserved firm attributes as potentially confounding factors. The results are consistent and the inferences are therefore the same as for our main results.

\section{Conclusions}

In this study we examined the financial implications for unlisted firms in Korea of adopting IFRS voluntarily, and quantified the changes following IFRS adoption by assessing the proxies of earning quality and the cost of debt. Because IFRS adoption is mandatory only for listed firms in Korea, the implications of IFRS adoption by unlisted firms is under-researched. This research therefore contributes to the body of knowledge on this topic by confirming the motivating factors that lie behind unlisted firms' voluntary adoption of IFRS and analysing the effects of IFRS adoption. Because unlisted firms can choose between two accounting standards, most apply KGAAP due to the higher cost of using IFRS. However, the results presented herein confirm that unlisted firms in Korea benefit from IFRS adoption via a lower cost of debt. This finding is not only of practical relevance for firms that plan to adopt IFRS but may also provide a useful argument for promoting the benefits of adoption. Moreover, we showed that firms adopting IFRS have higher earnings quality compared with firms that use KGAAP. The approximately 18,000 unlisted firms in Korea are important economic units in the growth of Korean industry. If they all adopted IFRS voluntarily, a considerable proportion of the financial information on the main production units in Korea's capital market would acquire more transparency and higher credibility, thereby mitigating the negative image of Korea discount. This paper is based on the proxy of earnings quality that is estimated from model, and thus subject to any biases embedded in the model. But out results provide new information that may stimulate further research on the credit evaluation of unlisted firms as well as loan appraisals by financial institutes for unlisted firms. Finally, given the lack of studies of unlisted firms compared with listed ones, these results improve our understanding of unlisted firms in general and may help guide future studies of this type.

\section{Acknowledgements}

We thank Sang Ha Lee for her research assistance of data analysis.

\footnotetext{
${ }^{5}$ Even though industry and time dummies are included in OLS model, omitted variables may cause asymptotic bias or inconsistency in non-experimental world. These can be reduced by using fixed effect model. We appreciate the helpful comments on firm-fixed effect model using unbalanced panel data made by an anonymous referee.
} 


\section{Funding}

This work was supported by the Kumoh National Institute of Technology; and the Korea Research Foundation Grant funded by the Korean Government (NRF2012S1A5A8024250).

\section{References}

Ahmed, A. S.; Rasmussen, S. J.; Tse, S. 2008. Audit quality, alternative monitoring mechanism, and cost of capital: an empirical analysis, Working paper. Texas A\&M University.

Armstrong, C.; Barth, M.; Jagolinzer, A.; Riedl, E. 2010. Market reaction to the adoption of IFRS in Europe, Accounting Review 85:31-61. http://dx.doi.org/10.2308/accr.2010.85.1.31

Ashbaugh, H. 2001. Non-US firms' accounting standard choices, Journal of Accounting and Public Policy 20: 129-153. http://dx.doi.org/10.1016/S0278-4254(01)00025-4

Ashbaugh, H.; Pincus, M. 2001. Domestic accounting standards, international accounting standards and the predictability of earnings, Journal of Accounting Research 39: 417-434.

http://dx.doi.org/10.1111/1475-679X.00020

Auer, K. V. 1996. Capital market reaction to earnings announcements: empirical evidence on the difference in the information content of IAS based earnings and EC-Directives based earnings, The European Accounting Review 5(4): 587-623. http://dx.doi.org/10.1080/09638189600000039

Ball, R.; Robin, A.; Wu, J. S. 2003. Incentives versus standards: properties of accounting income in four East Asian countries, Journal of Accounting and Economics 36(1-3): 235-270.

http://dx.doi.org/10.1016/j.jacceco.2003.10.003

Barth, M.; Landsman, W.; Lang, M. 2008. International accounting standards and accounting quality, Journal of Accounting Research 46: 467-498.

http://dx.doi.org/10.1111/j.1475-679X.2008.00287.x

Barth, M.; Landsman, W.; Lang, M.; Williams, C. 2012. Are IFRS-based and US GAAP-based accounting amounts comparable?, Journal of Accounting and Economics 54: 68-93.

http://dx.doi.org/10.1016/j.jacceco.2012.03.001

Becker, C.; DeFond, M.; Jiambalvo, J.; Subramanyam, K. 1998. The effect of audit quality on earnings management, Contemporary Accounting Research 15: 1-24.

http://dx.doi.org/10.1111/j.1911-3846.1998.tb00547.x

Beuselinck, C.; Joos, P.; Khurana, I.; Van der Meulen, S. 2009. Mandatory IFRS reporting and stock price informativeness, Working Paper. Tilburg University and University of Missouri at Columbia.

Brochet, F.; Jagolinzer, A. D.; Riedl, E. J. 2013. Mandatory IFRS adoption and financial statement comparability, Contemporary Accounting Research 30(4):1373-1400.

http://dx.doi.org/10.1111/1911-3846.12002

Capkun, V.; Collins, D.; Jeanjean, T. 2011. Does adoption of IAS/IFRS deter earnings management?, Working Paper. HEC Paris, University of Iowa, and ESSEC Business School.

Choi, K.; Choe, K. H. 2003. An analysis of the corporate characteristics of companies reporting aggressive accounting, Korean Accounting Review 28: 211-243.

Christensen, H.; Lee, E.; Walker, M. 2008. Incentives or standards: what determines accounting quality changes around IFRS adoption?, Working Paper. University of Manchester.

Christensen, H. B.; Hail, L.; Leuz, C. 2013. Mandatory IFRS reporting and changes in enforcement, Journal of Accounting and Economics 56: 147-177.

http://dx.doi.org/10.1016/j.jacceco.2013.10.007 
Covrig, V. M.; DeFond, L.; Hung, M. 2007. Home bias, foreign mutual fund holdings, and the voluntary adoption of international accounting standards, Journal of Accounting Research 45: 41-70. http://dx.doi.org/10.1111/j.1475-679X.2007.00226.x

Cuijpers, R.; Buijink, W. 2005. Voluntary adoption of non local GAAP in the European Union: a study of determinants and consequences, European Accounting Review 14(3): 487-524. http://dx.doi.org/10.1080/0963818042000337132

Daske, H.; Hail, L.; Leuz, C.; Verdi, R. 2008. Mandatory IFRS reporting around the world: early evidence on the economic consequences, Working Paper. University of Chicago Graduate School of Business.

Dechow, P.; Sloan, R.; Sweeney, A. 1995. Detecting earning management, The Accounting Review 70: 193-225.

Defond, M. L.; Jiambalvo, J. 1994. Debt covenant effects and the manipulation of accruals, Journal of Accounting and Economics 17: 145-176. http://dx.doi.org/10.1016/0165-4101(94)90008-6

Dhaliwal, D. S.; Gleason, C. A.; Heizman, S.; Melendrez, K. D. 2008. Auditor fees and cost of debt, Journal of Accounting Auditing and Finance 23(1): 1-22.

Fernando, G. D.; Elder, R. J.; Abdel-Meguid, A. M. 2008. Audit quality attributes, client size and cost of capital, Working paper. Syracuse University.

Francis, J.; Khurana, I. K.; Pereira, R. 2005a. Disclosure incentives and effects on cost of capital around the world, Accounting Review 80(4):1125-1162.

http://dx.doi.org/10.2308/accr.2005.80.4.1125

Francis, J.; Krishnan, J. 1999. Accounting accruals and auditor reporting conservatism, Contemporary Accounting Research 16: 135-165. http://dx.doi.org/10.1111/j.1911-3846.1999.tb00577.x

Francis, J.; LaFond, R.; Olsson, P.; Schipper, K. 2004. Costs of equity and earnings attributes, The Accounting Review 79(4): 967-1010. http://dx.doi.org/10.2308/accr.2004.79.4.967

Francis, J.; LaFond, R.; Olsson, P.; Schipper, K. 2005b. The market pricing of accruals quality, Journal of Accounting and Economics 39(2): 295-327.

http://dx.doi.org/10.1016/j.jacceco.2004.06.003

Gassen, J.; Sellhorn, T. 2006. Applying IFRS in Germany-determinants and consequences, Bfup 58(4): 365-386.

Ge, W.; Kim, J. B. 2010. Real earnings management and cost of debt, Working paper. City university of Manitoba.

Gebhardt, G.; Novotny-Farkas, Z. 2011. Mandatory IFRS adoption and accounting quality of European banks, Journal of Business Finance and Accounting 38: 289-333.

http://dx.doi.org/10.1111/j.1468-5957.2011.02242.x

Gordon, E.; Jorgensen, B.; Linthicum, C. 2009. Could IFRS replace U.S. GAAP? A comparison of earnings attributes and informativeness in the U.S. market, Working Paper. Temple University, University of Colorado, University of Texas at San Antonio.

Hail, L.; Leuz, C.; Wysocki, P. 2010. Global accounting convergence and the potential adoption of IFRS by the U.S. (part I): conceptual underpinnings and economic analysis, Accounting Horizon 24: 355-394. http://dx.doi.org/10.2308/acch.2010.24.3.355

Harris, M.; Muller, K. 1999. The market valuation of IAS versus US GAAP accounting measures using form 20-F reconciliations, Journal of Accounting and Economics 26(1-3): 285-312. http://dx.doi.org/10.1016/S0165-4101(99)00003-8

Heckman, J. 1979. Sample selection bias as a specification error, Econometrica 47(1): 153-161. http://dx.doi.org/10.2307/1912352

Hope, O. K.; Kang, T.; Thomas, W.; Yoo, Y. K. 2009. Impact of excess auditor remuneration on cost of equity capital around the world, Journal of Accounting Auditing and Finance 24(2): $177-210$. 
Horton, J.; Serafeim, G.; Serafeim, I. 2013. Does mandatory IFRS adoption improve the information environment?, Contemporary Accounting Research 30: 388-423.

http://dx.doi.org/10.1111/j.1911-3846.2012.01159.x

Hung, M.; Subramanyam, K. R. 2007. Financial statement effects of adopting international accounting standards: the case of Germany, Review of Accounting Studies 12(4): 21-48.

http://dx.doi.org/10.1007/s11142-007-9049-9

Jeanjean, T.; Stolowy, H. 2008. Do accounting standards matter? An exploratory analysis of earnings management before and after IFRS adoption, Journal of Accounting and Public Policy 27: 480-494. http://dx.doi.org/10.1016/j.jaccpubpol.2008.09.008

Kang, S. M.; Han, B. H.; Hwang, I. T. 2009. Effect of the international financial reporting standards on financial statements in the U.K. and Australia, Korean Accounting Journal (18): 281-312.

Khurana, J. K.; Raman, K. K. 2004. Litigation risk and the financial reporting credibility of Big 4 versus non-Big 4 audits: evidence from Anglo-American countries, The Accounting Review 79(2): 473-495. http://dx.doi.org/10.2308/accr.2004.79.2.473

Kim, H. Y.; Park, M. Y. 2010. The effects of the audit fee on conservatism and cost of capital, Journal of Finance and Accounting Information 10(1): 81-111.

Kim, J. B.; Sohn, B. C. 2008. Real versus accrual-based earnings management and implied cost of equity capital, Working paper. City University of Hong Kong.

Kim, J. B; Simmunic, D. A.; Stein, M. T.; Yi, C. H. 2011. Voluntary audits and the cost of debt capital for privately held forms: Korean evidence, Contemporary Accounting Research 28(2): 585-615. http://dx.doi.org/10.1111/j.1911-3846.2010.01054.x

Kim, Y. S. 2011. The effects of early adoption of K-IFRS on information asymmetry and quality of earnings, Accounting Information Review 29(4): 273-299.

Kim, Y. S.; Kang, S. A. 2010. A study on the factors attracting early adoption of K-IFRS and the effects, Korean Accounting Journal (19): 89-115.

Kothari, S. P.; Leone, A. J.; Wasley, C. E. 2005. Performance matched discretionary accrual measures, Journal of Accounting and Economics 39: 163-197.

http://dx.doi.org/10.1016/j.jacceco.2004.11.002

Leuz, C.; Verrecchia, R. 2000. The economic consequences of increased disclosure, Journal of Accounting Research 38: 91-124. http://dx.doi.org/10.2307/2672910

Lou, Y.; Vasvari, F. P. 2009. Auditor specialization and the cost of debt, Working paper. London Business School.

McInnis, J. 2010. Earnings smoothness, average returns, and implied cost of equity capital, The Accounting Review 85(1): 315-341. http://dx.doi.org/10.2308/accr.2010.85.1.315

Moon, H. J. 2011. A comparison of earnings persistence under Korean GAAP versus IFRS, Taxation and Accounting Journal 12: 45-68.

Petersen, M. A. 2009. Estimating standard errors in finance panel data sets: comparing approaches, Review of Financial Studies 22: 435-480. http://dx.doi.org/10.1093/rfs/hhn053

Pittman, J. A.; Fortin, S. 2004. Auditor choice and the cost of debt capital for newly public firms, Journal of Accounting and Econometrics 37(1): 113-136.

http://dx.doi.org/10.1016/j.jacceco.2003.06.005

Tan, H.; Wang, S.; Welker, M. 2011. Analyst following and forecast accuracy after mandated IFRS adoptions, Journal of Accounting Research 49: 1307-1357.

http://dx.doi.org/10.1111/j.1475-679X.2011.00422.x

Xie. B.; Davidson III, W. N.; Dadalt, P. J. 2003. Earning management and corporate governance: the role of the board and the audit committee, Journal of Corporate Finance 9: 295-316. 
Yang, D. H.; Lee, S. C.; Yoon, J. C. 2011. The effect of voluntary disclosure quality on the cost of debt, Business Administration Research 40: 803-830.

Yeo, E. J.; Koh, Y. S.; Kim, J. H. 2007. The effects of the IFRS on the financial statement: adoption of IFRS: German, United Kingdom, Hong Kong, International Accounting Research 19: 175-201.

Yoon, S. S. 1998. A study of earnings management using cash flows from operations, Korean Accounting Review 23: 107-126.

\section{APPENDIX}

\section{Variable definitions}

\section{Dependant variables}

$D A$ : Discretionary accruals estimated by the modified Jones model

(Kothari et al. 2005)

$C_{-} D E B T_{1}$ : Interest rate (Interest expenses/Average debt)

$C_{-} D E B T_{2}:$ Fractional rank variable based on $C_{-} D E B T_{1}$ (five groups)

\section{Independant variables}

IFRS: Dummy variable that equals 1 if firm adopts IFRS and 0 otherwise

Post_IFRS: Dummy variable that equals 1 if firm adopts IFRS after year $t$ and 0 otherwise

$S I Z E$ : Natural log of total assets

$R O A$ : Return on assets (Earnings before Tax/Total Assets)

$L E V$ : Debt ratio (Total Debt/Total Assets)

BIG4: Dummy variable that equals 1 if the firm's auditor belongs to the Big4 auditors and 0 otherwise

$P P E$ : Fixed asset ratio (Property, plant, and equipment/Total Assets)

$G R W$ : Growth rate (Change in sales/Opening assets)

$N E G E$ : Dummy variable that equals 1 if the firm's total equity is below its capital and 0 otherwise

Mills: Inverse Mills Ratio from the first stage of Model 1

SI_Dum: Industry dummy variables

$\Sigma Y \_$Dum: Year dummy variables

Note: This table provides definitions of the variables that were used in this study. Data were obtained from TS-2000 and KIS-VALUE III.

Young Hwan LEE received PhD in Banking and Finance at the Univ. of Georgia in USA. He worked as a vice director at Busan commercial bank conducting credit analysis. He is a professor of Business department at Kumoh National Institute of Technology now. Several ongoing projects are corporate governance and capital structure, the effect of dividend policy on equity offering, and so on.

Sun A KANG got PhD in Business administration at Sogang Univ. in Korea. She worked as an AICPA at PWC Samil accounting firm and as a senior researcher at ETRI. Currently, she is an associate professor of Chungnam National University. Her research interests are financial accounting, especially earnings management, corporate governance, and regulatory cost accounting.

Sang Min CHO got PhD in Business administration of Hanyang Univ. He has worked as a KICPA at Sinwoo accounting firm for 13 years. He is now an assistant professor of Hannam University in Korea. He has interested in financial accounting, tax, auditing, and corporate governance. 